\title{
Sosyo
}

Ekonomi

\section{Türkiye İmalat Sanayiinde Ölçek Bazında Kârlılık ve Temel Giderler İlişkisi: 1998-2009 Dönemi}

\author{
Cemil ÇİFTÇİ \\ cemilc@pau.edu.tr
}

\section{The Relationship between Profitability and Basic Expenses in Scale Level of Turkish Manufacturing Sector: 1998-2009}

\begin{abstract}
This study examine the effects of research and development (R\&D), advertising, marketing and distribution and general management expenses on firms and analysis these variables effects on gross profit margin for small, medium-sized, and large firms with Turkish Manufacturing subsectors data by empirically. Our empirical results show that for the small size only advertising, marketing and distribution expenses is significant, for medium-sized firms R\&D and advertisement, marketing and distribution is significant, but general management expenses is not. For the large firms all variables are significant, but the most important variable on gross profit margin is the general administrative expenses. The result of $R \& D$ effect on gross profit margin in medium-sized firms is bigger than in large firms is quite important for policy makers.
\end{abstract}

Keywords : Manufacturing, R\&D, Marketing and Advertising.

JEL Classification Codes : $\quad$ L60, O30, M30.

\section{Özet}

Çalışmada, araştırma geliştirme, reklam, pazarlama ve dağıtım ile genel yönetim giderlerinin firmalar üzerindeki olası etkileri teorik olarak incelerek, 1998-2009 döneminde Türkiye'de imalat sanayi alt sektörlerindeki küçük, orta ve büyük ölçekli firmalarda bu değişkenlerin brüt kâr marjı üzerinde etkisi analiz edilmiştir. Ampirik sonuçlar küçük firmalarda yalnızca reklam, pazarlama ve dağıtım giderlerinin, orta ölçekli firmalarda ise araştırma geliştirme ve reklam, pazarlama ve dağıtım giderlerinin brüt kâr marjı üzerindeki etkisinin anlamlı olduğunu göstermektedir. Büyük ölçekli firmalarda bütün değişkenlerin etkisi anlamlı bulunurken, en büyük etkiye sahip değişkenin genel yönetim giderleri olduğu sonucuna ulaşılmıştır. Orta ölçekli firmalarda araştırma geliştirme harcamalarının brüt kâr marjı üzerindeki etkisinin büyük ölçekli firmalara kıyasla daha büyük bulunması, politika yapıcıları için oldukça önemli bir sonuçtur.

Anahtar Sözcükler
: İmalat Sanayii, Araştırma Geliştirme, Pazarlama ve Reklam. 
Cemil ÇiFTÇi 


\section{Giriş}

İktisat teorisinin firmalara yönelik en temel varsayımı firmaların kârlarını maksimize edecek biçimde davrandıklarıdır. Geleneksel iktisat teorisi firmalar arasında kârlılık bakımından kısa dönemde ortaya çıkan farklılıkların, uzun dönemde ortadan kalkacağını ve uzun dönemde kâr oranlarının (normal kâr) eşitleneceği öngörmektedir. Bununla birlikte günümüz aksak rekabet piyasası koşullarında gerek aynı endüstrideki, gerekse farklı endüstrilerdeki firmalar arasındaki kâr oranlarındaki farklılıklar tartışılmaz bir gerçektir. Bu durum, literatürde firmaların kârlılıkları üzerine yapılan çalışmaları sürekli gündemde tutmaktadır.

Firmaların kârlılıkları arasındaki farklılıkların temel nedenleri arasında, Chandler (1992)'ın ifade ettiği gibi, 19. yüzyılın sonlarında ve 20. yüzyılda özellikle ulaştırma ve iletişim ağlarındaki gelişmeye paralel olarak ortaya çıkan ve sermaye yoğunluğu daha yüksek, ölçek ve kapsam ekonomilerinden yararlanabilen endüstriyel girişimlerin, potansiyel maliyet avantajlarından yararlanması bulunmaktadır. Chandler'a (1992) göre, 20. yüzyıldaki sermaye yoğun endüstriyel firmaların kârlılıklarının; fiziki üretim yatırımları, pazarlama, dağıtım yatırımları ve yöneticilere yönelik yatırımlardaki başarılara bağlı olarak analiz edilmesi gerekmektedir. Özellikle firmaların temel yatırımları arasında değerlendirilebilecek araştırma-geliştirme (Ar-Ge) ve reklam, pazarlama ve dağıtım (RPD) harcamaları bir taraftan firmaların bireysel talep eğrisini sağa doğru kaydırırken, diğer taraftan da karşılaştıkları talebin fiyat esnekliğini azaltmaktadır (Caves ve Porter, 1977). Söz konusu harcamalar, özellikle küçük ve orta ölçekli firmalar için finansal kaynaklara erişebilme sorunlarını da beraberinde getirebilmektedir (Beck, Demirguc-Kunt ve Maksimovic, 2005) ${ }^{1}$. Finansman kısıtları ise, özellikle piyasalara girişteki engellerin ve yoğunlaşmanın artmasına neden olarak, büyük ölçekli firmalara avantajlar sağlayabilmektedir².

Taymaz (2001), 1970 ve 1980’li yıllarda küçük ve orta ölçekli firmaların emek yoğun teknolojik yapılarıyla istihdamı artıran özellikleri üzerinde yoğunlaşılırken, 2000'li yıllarda ise küçük ve orta ölçekli firmalar teknolojik gelişim ve girişimcilik ruhları ile gösterdikleri esneklik ve yaratıcılık özellikleri çerçevesinde analiz edilmeye başlanıldığını ifade etmektedir. Dolayısıyla, küçük ve orta ölçekli firmalar bir taraftan istihdam

1 Firmaların büyümesindeki finansal ve yasal kısıtlar ile büyüme arasındaki etkileşim hakkında ülke karşılaştırmaları için bkz. Beck, Demirguc-Kunt ve Maksimovic (2005). Ayrıca, küçük ve orta ölçekli firmaların finansal kaynaklara ulaşmada yaşadıkları zorluklar konusunda yapılan deneysel çalışmalar hakkında ayrıntılı bilgi için bkz. Beck ve Demirguc-Kunt (2006).

2 Becchetti and Trovato (2002) Italyan imalat sanayi için 1989-92, 1992-94, 1995-97 olmak üzere üç dönemde yaptıkları çalışmada söz konusu dönemlerde hayatta kalabilmeyi başarabilen küçük firmaların ortalama büyüme potansiyellerinin daha büyük olduğunu, ancak büyüme potansiyelinin firma dişı finansman kaynaklarının kıtlığı ve yabancı piyasalara girişteki zorluklar gibi nedenlere bağlı olarak kısıtlandı̆̆ını ileri sürmektedirler. Carpenter ve Petersen (2002)'de, 1600'den fazla imalat firması üzerine yaptıkları çalışmada küçük firmaların içsel finansman olanaklarındaki kisitın firmaların büyümesi önündeki en önemli engel olduğu sonucunu ulaşmışlardır. 
yaratırken, diğer taraftan söz konusu yeni özellikleriyle ülkelerin yapısal dönüşümünde de önemli roller üstlenebilmektedirler.

$\mathrm{Bu}$ çalışmanın amacı, imalat sanayii alt sektörlerinde Ar-Ge, reklam, pazarlama ve dağıtım (RPD) ile genel yönetim giderlerinin (GYG) küçük, orta ve büyük ölçekli firmaların brüt kâr marjı üzerindeki etkilerini ayrı ayrı analiz ederek, imalat sanayii temelinde firmalara yönelik politika önerileri için bir çerçeve oluşturabilmektir. Çalışmamızda imalat sanayindeki 9 alt sektöre ait 1998-2009 döneme ilişkin veriler kullanılmıştır.

\section{Literatür Taraması}

Firma büyüklüğü ile kârlılık arasındaki ilişki literatürde yoğun olarak çalışılan alanlardan biridir. Kârlılık bir yandan firmaların fiyatlama davranışlarının bir sonucunu ifade ederken, diğer yandan özellikle uzun dönemde endüstri düzeyinde ortaya çıkabilecek rekabet hakkında da ipuçları vermektedir. Genel olarak Ar-Ge ve RPD olanakları ile sermaye yoğun üretim, büyük firmaların sahip olduğu üstünlükler olarak ele alınsa da, literatürde kârlılık ve büyüklük arasındaki ilişkiyi belirlemeye yönelik çalışmalarda üzerinde fikir birliği sağlanmış bir çerçeve bulunmamaktadır. Amato ve Wilder (1985) literatürde firma büyüklüğü ve kârlılık arasındaki ilişki üzerine yapılan ampirik çalışmaları dört temel başlık altında toplamaktadır; ölçek ekonomileri, piyasa aksaklıkları, stratejik gruplar ve son olarak yoğunlaşma ve piyasa payının kârlılık üzerindeki göreli önemi.

Özellikle 20. yüzyılın son çeyreğinden itibaren ileri teknolojili mal üreten sektörlerin ortaya çıkışı, literatürde firmaların piyasa payı, ölçek ekonomileri ve piyasaya giriş engellerinin kârlılık üzerindeki etkilerine yönelik bakış açısının da değişmesine neden olmuştur³ ${ }^{3}$ Philllips (1991) Amerikan ekonomisi üzerine yaptığı çalışmada, 1970’lerden sonra ölçek ekonomilerinin daha önceki dönemler kadar önem taşımadığını ileri sürerken temel olarak savını, özellikle ileri teknoloji mal üreten sektörlerde ürün yaşam dönemlerinin kısalmasına bağlamaktadır ${ }^{4}$. Bu durum söz konusu sektörlerdeki küçük firmalar açısından çeşitli avantajlara neden olabilmektedir ${ }^{5}$. Dhawan (2001)'ın 1970-1989 döneminde Amerikan borsasında işlem gören firmalar üzerine yaptığı çalışmada küçük firmalardaki kârlılık oranlarının büyük firmalardan daha yüksek olduğu, bununla birlikte

3 Söz konusu değişimde iktisat teorisi literatüründe firmaya ve firma yönetimine bakışta da değişimler olmuştur. Ayrıntılı bir teorik değerlendirme için bkz. Nelson (1991).

4 Firmaların ölçek ekonomisinden yararlanabilmeleri belirli bir büyüklüğe ulaşmalarına bağlıdır. Ancak, teknolojideki hızl gelişmeler (ürün yaşam döneminin hızlı bir şekilde tamamlanmasına neden olarak) söz konusu sektörlerdeki firmaların ölçek ekonomisi sağlayabilecek büyüklüğe ulaşamamasına neden olabilmektedir. Bu nedenle özellikle ileri teknolojili mal üreten sektörlerde, küçük ve orta ölçekli firmaların kârlılıklarl daha yüksek olabilmektedir (Dhawan, 2001). Ayrıca firmaların ölçek ekonomilerinden yararlanmalart yeterli atıl kapasiteye ve organizasyonel sisteme sahip olmalarlyla da ilişkilidir (Ammar ve ark., 2003).

5 Phillips (1991), ayrıca ileri teknoloji mal üreten ve hayatta kalmayı başarabilen küçük firmaların, hem büyük firmalardan hem de ileri teknoloji mal üretmeyen sektörlerdeki küçük firmalardan daha hızl büyüdügünü belirtmektedir. 
küçük firmalardaki hayatta kalabilme olasılığının ise daha düşük olduğu sonucunu da, Phillips'in savını destekler niteliktedir.

20. yüzyıldaki endüstri ve firma yapısındaki ortaya çıkan değişikliklerden bir diğeri, firma büyüklüğü arttıkça firma sahipliği ile yönetimin ayrışması olmuştur. Bu durum, firmaların kâr maksimizasyonu davranışına ek olarak yöneticilerin fayda fonksiyonu davranışının da kârlılık analizlerinde değerlendirilmesini beraberinde getirmiştir. Firma sahibinin kâr maksimizasyonu güdüsü ile yöneticinin fayda fonksiyonu ${ }^{6}$ arasında ortaya çıkabilecek farklılaşmalar, firma büyüklüğü ile kârlılık arasında negatif bir ilişkiye neden olabilmektedir (Williamson, 1963; Alchian, 1965). Diğer bir deyişle yöneticilerin fayda maksimizasyonuna yönelik davranışları, firmaların kâr maksimizasyonu davranışlarıyla örtüşmeyebilmektedir.

Hansen ve Wernerfelt (1989) iktisadi ve organizasyonel faktörlerin ${ }^{7}$ firma performansı üzerindeki etkilerini belirlemeye yönelik yaptıkları çalışmada, gerek organizasyonel (firma içi faktörler), gerekse iktisadi faktörlerin firma performansını önemli ölçüde açıklamasına karşın, organizasyonel faktörlerin firma kârlarındaki değişmeyi iktisadi faktörlerden yaklaşık iki kat daha fazla etkilediği sonucuna ulaşmışlardır. Bu nedenle, çalışmamızda organizasyonel faktörler arasında değerlendirilen Ar-Ge, RPD ve GYG'ne yönelik literatür kapsamlı olarak alt başlıklar altında ele alınmıştır.

\subsection{Araştırma-Geliştirme Giderleri}

20. ve 21. yüzyılda yeni mal ve/veya üretim süreçlerinin temel kaynağı olarak Ar-Ge faaliyetlerinin önemi, gerek firmalar gerekse ülkeler açısından oldukça artmıştır. Ar-Ge faaliyetleri sonucunda elde edilen yeni ürün ve/veya üretim süreçleri firmaların piyasa payını, rekabet gücünü ve etkinliğini artırmakta, ayrıca piyasaya giriş engelleri yaratabilmektedir ${ }^{8}$. García-Manjón ve Romero-Merino (2012), 2003-2007 döneminde 18 Avrupa ülkesindeki 754 firma üzerine yaptıkları çalışmada, Ar-Ge harcamalarının firmaların piyasa payı üzerinde pozitif bir etkisi olduğu ve firmaların satışları, büyümesi ve hayatta kalma olasılıklarını artırdığı sonucuna ulaşmışlardır9 Ayrıca García-Manjón ve

6 Yöneticilerin fayda fonksiyonundaki kişisel ücret, iş güvenliği, güç, prestij, terfi etme gibi olgular kişisel çıkarlar ile firma çıkarlarının farklılaşmasına neden olabilmektedir (Williamson, 1963).

7 Hansen and Wernerfelt (1989) çalışmalarında iktisadi faktörler olarak firma - endüstri kârlıllğı ile piyasa payl ve firma büyüklügünü; organizasyonel faktörler olarak ise firmalardaki iletişim özelliklerini, beşeri kaynakları, karar verme süreçleri ile hedeflerin, iş ve meslek dizaynının organizasyonunu ele almışlardır.

8 Ar-Ge ile kârlılık arasında iki yönlü bir ilişki bulunmaktadır (Scherer, 2001); Ar-Ge sonucunda bulunan yeni ürün ve/veya üretim süreçleri firmaların karlllı̆̆ını artırırken, diğer taraftan artan kârlar da Ar-Ge harcamalarını finanse etmek için bir kaynak oluşturacakttr.

9 Nadiri ve Kim (1996) ise 1974-1990 döneminde Amerika, Japonya ve Kore'deki imalat sanayi sektöründeki çıtı ve verimlilik büyümesini analiz ettikleri çalışmada söz konusu dönemde Japonya ve Kore'de çıtı ve verimlilik büyümesindeki temel faktörlerin işgücü kaynaklar ile fiziki ve Ar-Ge sermaye yatırımlarına dayandiğı, Amerika'daki çıktı büyümesindeki yavaşlamanın ise özellikle sermaye ve işgücünün yavaş büyümesinden kaynaklandığı sonucuna ulaşmışlardır. 
Romero-Merino (2012), özellikle yüksek teknolojili sektörlerde Ar-Ge yatırımlarının kârlılık üzerindeki etkisinin kesin olmakla birlikte, düşük teknolojili sektörlerde bu etkinin gözlenemediğini de belirtmektedir. Chiao, Yang ve Yu (2006)'nun yeni sanayileşmiş ülkelerdeki tekstil ve elektronik sektöründeki küçük firmalar üzerine yaptıkları çalışmada ise Ar-Ge yatırımları ile performans arasında pozitif bir ilişki olduğu vurgulanmaktadır. Archarungroj ve Hoshino (1999) Japonya ulusal borsasında kimya ve farmasotik endüstrilerinde faaliyette bulunan 170 firma üzerine yaptıkları çalışmada ise, Ar-Ge harcamaları ve Ar-Ge yoğunluğunun gerek firmaların faaliyet geliri, gerekse kârlılı̆̆ üzerinde pozitif ve anlamlı etkisi olduğunu ortaya koyarken, büyük firmaların küçük firmalarla karşılaştırıldıklarında Ar-Ge yönetimindeki etkinliklerinin daha büyük olduğu sonucuna ulaşmışlardır. Genel olarak, Ar-Ge ve yenilik ${ }^{10}$ faaliyetleri bir taraftan firmalara ulusal ve uluslararası rekabet ortamında önemli avantajlar sağlayarak firmaların performanslarını pozitif olarak etkilerken, diğer taraftan az gelişmiş ülkelerin gelişmekte olan ülkeleri yakalama sürecinde en önemli faktörler arasında yer almaktadır.

Ar-Ge faaliyetlerinin günümüz rekabet koşullarında firmalara sağladığ avantajlara karşın, özellikle her geçen gün yoğunlaşan rekabet ortamında söz konusu faaliyetlerin finansmanı, küçük ve orta ölçekli firmalar için önemli bir sorun olmaktadır. Hall ve Lerner (2009), küçük firmaların finans sorunlarının arkasında yatan temel savı; ArGe ve yenilik faaliyetleri sonucunda ortaya çıkan yeni mal ve hizmetlerin nasıl üretileceği hakkındaki bilginin ${ }^{11}$, diğer firmalar tarafından kullanılmasının engellenememesine dayandırmaktadırlar. Söz konusu bilginin bir sir olarak tutulamaması ise Ar-Ge yatırımlarının getirisini azaltarak, küçük firmaların Ar-Ge'ye yatırım yapmada isteksiz olmalarına neden olabilmektedir. Bu durum Comanor (1967)'un ifade ettiği gibi büyük firmaların, küçük firmalara oranla daha fazla Ar-Ge harcaması yapmasına ve ayrıca büyük firmaların Ar-Ge faaliyetlerinde devamlılığı sağlayabilmesine neden olabilmektedir ${ }^{12}$.

20. yüzyılın sonu ve 21. yüzyılda teknoloji ve üretilen malların niteliğindeki hızlı değişmeler, piyasada rekabet gücünün sürekliliği için Ar-Ge faaliyetlerine yapılan yatırımın devamlılığını da zorunlu hale getirerek, finansman sorununun büyümesine neden olmuştur. McAlister, Srinivasan ve Kim (2007)'in firmaların reklam ve Ar-Ge harcamalarındaki azalışın yalnızca firmaların finansal performansını ve hisse senedi getirisini azaltmadığını, aynı zamanda firmaların sistematik riskini, sermayenin maliyetini ve iskonto oranını artırdığı sonucu da, söz konusu harcamalarda devamlılığın önemini açıkça ortaya koymaktadır. Candemir ve Zalluhoğlu (2011)'nun 1997-2010 döneminde

10 Acs ve Audretsch (1988) 'in endüstrideki Ar-Ge harcamalarındaki artışın yenilik sayısını azalan oranlarda da olsa artırdığ sonucu, Ar-Ge faaliyetlerinin yenilik açısından önemini ortaya koymaktadır. Audretsch (1991) 1976 yllında imalat sanayinde faaliyet gösteren 11.000 firma üzerine yaptığ çalışmada, $1980-84$ yıllarl arasındaki dönem için yenilik oranlarının küçük firmalardaki hayatta kalma olasılıkları üzerindeki etkisinin de pozitif ve anlamlı olduğu sonucuna ulaşmıştır.

11 Hall ve Lerner (2009), Ar-Ge sonucunda elde edilen bilgilerin rakipsizlik özelliğine sahip olduğunu ifade etmektedir.

12 Comanor (1967) ayrıca Ar-Ge harcamalarının, özellikle araştırmanın mal farklılaştırmasını teşvik ettiği ve kolaylaştırdı̆̆ durumlarda daha önemli olduğunu vurgulamaktadır. 
özellikle kriz dönemlerinde IMKB'deki gıda firmalarının Ar-Ge ve pazarlama harcamalarının satışlar üzerindeki etkilerini analiz ettikleri çalışmada, kriz dönemlerinde firmaların gerek Ar-Ge gerekse pazarlama harcamalarının, kriz sonrası dönemdeki rekabet güçlerinin devamı için önemli olduğu sonucu da, bu görüşü desteklemektedir.

Teknolojideki hızlı gelişmeler, 21. yüzyılda küçük firmaların büyük firmalara oranla daha kârlı olmasının nedenlerinden biri olarak değerlendirilmekle beraber, küçük firmaların büyük firmalara oranla hayatta kalabilme olasılıkları ${ }^{13}$ daha düşüktür. $\mathrm{Bu}$ durumun en önemli nedenlerinden biri ise Ar-Ge yatırımlarındaki devamlılığın sağlanamamasıdır ${ }^{14}$. Bu süreçte özellikle Audretsch ve Vivarelli (1996)'nin 1978-1986 döneminde İtalya'da 20 bölgedeki imalat sanayi firmaları üzerine yaptıkları çalışmanın sonuçları, özellikle gelişmekte olan ülkelerde üniversite-özel sektör işbirliğinin neden olacağı gelişmeleri ortaya koyması açısından oldukça önemlidir. Audretsch ve Vivarelli (1996) büyük firmalarda Ar-Ge harcamalarının yenilik çıktısı üretilmesindeki katkısının, küçük ve orta ölçekli firmalardan daha önemli olduğunu belirtmekle birlikte, küçük firmalarda üniversitelerle işbirliğinin yenilik çıktısı üretilmesinde anlamlı ve anahtar bir rolü olduğunu ortaya koymuşlardır ${ }^{15}$. Qian ve Li (2003) de ileri teknolojili biyoteknoloji endüstrisi üzerine yaptıkları çalışmada, söz konusu sektörlerdeki küçük firmaların sahip oldukları üstünlükleri koruyup devam ettirebilmeleri için önemli miktarlarda R\&D yatırımları yapmaları gerektiğini ${ }^{16}$ belirtirken, özellikle diş ticaretin de bu süreçte önemli katkılarının olabileceğini ortaya koymuşlardır. Özçelik ve Taymaz (2004), Türkiye'de ArGe ve yeniliklerin imalat sanayindeki firmaların uluslararası rekabet gücünde hayati bir faktör olduğunun altına çizmektedirler. Dolayısıyla gerek küçük firmaların Ar-Ge faaliyetlerine üniversitelerin katkısı sağlanarak, gerekse söz konusu firmaları ihracata yönlendirerek, hem firmaların kârlılık ve rekabet gücü artırılabilir, hem de gelişmekte olan ülkelerin dış ticaret açıklarının azaltılmasında ve kalkınmasında önemli gelişmeler elde edilebilir. Özçelik ve Taymaz (2008)'ın kamu Ar-Ge desteklerinin özel Ar-Ge

13 Ahn (2001) OECD ülkeleri üzerine yaptı̆̆̊ çalışmada küçük firmaların piyasaya giriş döneminin başlangıcında daha hızlı büyümekle birlikte, bu firmaların hayatta kalma oranlarının düşük olduğu sonucuna ulaşmiştır.

14 Taymaz (2001), Türkiye'deki imalat sanayiindeki küçük ve orta ölçekli firmaların hayatta kalabilme oranlarının oldukça düşük olduğunu belirtirken, söz konusu firmaların ancak teknolojik dinamizmi elde etmeleri durumunda kalkınmada çok önemli roller üstlenebileceklerine dikkati çekmektedir. Çünkü söz konusu dinamizmin sağlanamaması durumunda, Audretsch, Houweling ve Thurik (2000)'in Hollanda imalat sanayii üzerine yaptıkları çalışmada ulaşılan Ar-Ge yoğun endüstrilerde hayatta kalma olasılığının daha düşük olması sonucu, kaçınılmaz hale gelebilir.

15 Licht ve Nerlinger (1998)'nın çalışmasının da Audretsch ve Vivarelli (1996)'yı destekler nitelikte olduğu söylenebilir. Licht ve Nerlinger (1998) yeni teknoloji temelli firmaların bulunduğu bölgelerdeki üniversitelerin bölgesel Ar-Ge varlıklarının, teknik okulların ve üniversite dışındaki Ar-Ge laboratuvarlarının bölgede kurulan yeni teknoloji temelli firmaların sayısını artırdığını ve ayrıca söz konusu bölgelerde teknolojinin yayılımını da sağladığını belirtmektedirler. Bu süreçte kamunun özel sektöre yapacağı katkıların da önemi ortaya çıkmaktadır.

16 Acs ve Audretsch (1989) Amerikan imalat sanayii üzerine yaptıkları çalışmada küçük firmaların piyasaya giriş davranışlarının Ar-Ge yoğunluğu ve piyasa yoğunlaşmasıyla negatif ilişkili olduğu, diğer bir deyişle ArGe yoğunluğu ve piyasa yoğunlaşması artışının piyasa giriş engellerini artırdı̆̆ sonucuna ulaşmışlardır. 
yatırımlarını anlamlı ve pozitif olarak etkilediği, ayrıca Türkiye'de Ar-Ge destek programına katılan küçük firmaların çıktı başına daha yüksek Ar-Ge yatırımlarının olduğunu, bu yüzden özellikle gelişmekte olan ülkelerde kamunun aktif olarak Ar-Ge yatırımlarını desteklemesi gerektiği sonuçları da, devletin üstlenmesi gereken roller açısından önemlidir.

\subsection{Reklam, Pazarlama ve Dağıtım Giderleri}

İktisat literatüründe reklamlar üç farklı özelliğiyle ele alınmıştır (Bagwell, 2007); ilki reklamların ikna edici özelliğidir. 20. yüzyılın ilk yarısında reklam, tüketicilerin zevk ve beğenilerini değiştirmesi, yapay mal farklılaştırması ve marka sadakati yaratmasıyla ele alınmıştır. $\mathrm{Bu}$ bakış açısında reklamın başlıca etkileri, firmaların mallarına yönelik talebin esnekliğini azaltarak, daha yüksek fiyatların belirlenmesini ve ayrıca piyasaya giriş engellerinin oluşturulmasını sağlamasıdır (Caves and Porter, 1977; Bass, Cattin ve Wittink, 1978). Dolayısıyla reklam harcamaları, tüketicilerin bir malı tüketmeye yönelik sadakatini sağlayarak, firmaların fiyatı belirleme ve değiştirme konusundaki gücünü artırmakta, bu durum ise Vernon ve Nourse (1973)'ün ortaya koyduğu gibi, özellikle büyük imalat firmalarındaki reklam harcamalarının yoğunluğu ile kâr oranları arasında pozitif ve anlamlı bir ilişkiyi beraberinde getirmektedir.

İkincisi reklamın bilgilendirici özelliğidir. Bu görüşe göre, birçok piyasa tüketicilerin eksik bilgisiyle biçimlenmiştir. Ancak araştırma maliyetleri tüketicilerin malın özellikleri, fiyatı ve kalitesi hakkında bilgi edinmesini engellemektedir ki reklam, tüketicileri doğrudan ve/veya dolaylı olarak bilgilendirilmesini sağlayarak araştırma maliyetlerini azaltmaktadır. Söz konusu çerçevede reklamın firmalar ve piyasa açısından en önemli etkileri; firmaların talep eğrilerinin daha esnek hale gelmesi, piyasadaki firmalar arasındaki rekabetin artması ve piyasaya girişleri kolaylaştırmasıdır. Üçüncüsü ise reklamların reklamı yapılan malın tamamlayıcısı olduğu görüşüdür ki, bu bakış açısında reklam tüketicilerin tercihlerini değiştirmeye yönelik değil, yalnızca onları bilgilendirmeye yönelik olarak ele alınmaktadır (Bagwell, 2007).

Piyasadaki rekabetin yoğunluğu ve/veya derecesine bağlı olarak endüstrilerde, kısıtlı finansal olanakların da etkisiyle, reklam harcamaları ve Ar-Ge harcamaları arasında ikame ve tamamlayıcılık ilişkisinin göreli olarak önemi değişebilmektedir. Laporta ve Jenkins (1996)'ın Kanada imalat sanayii üzerine yaptıkları çalışmada, reklam harcamalarının özellikle üretici malları üreten sanayilerde kârlılık üzerindeki etkisinin anlamlı, pozitif ve büyük olduğu, bununla birlikte reklamın tüketici malları sanayilerinde, maliyetli bir fiyat dışı rekabet biçimi olmasının da etkisiyle, kârlılık üzerinde anlamlı, pozitif ancak küçük bir etkisi olduğu sonucuna ulaşılmıştır. Bununla birlikte, Lee and Mahmood (2009)'un Kore imalat sanayi üzerine yaptıkları çalışmanın sonucu, reklam harcamalarının yoğun piyasa rekabetinin olduğu tüketici malları endüstrilerinde (reklam ile Ar-Ge harcamaları arasında daha çok ikame ilişkisinin olduğu), üretici malları (reklam ile Ar-Ge harcamaları arasında daha çok tamamlayıcı ilişkisinin olduğu) endüstrilerine göre yüksek kârlılığın korunmasında ve/veya artırılmasında daha etkin olduğunu göstermektedir. Ayrıca, Lee ve Mahmood (2009), özellikle yoğun rekabet durumunda uzun dönemli Ar-Ge yatırımlarının daha riskli olmasına bağlı olarak, üretici malları 
endüstrilerinde (reklamın kalitenin de bir göstergesi olarak değerlendirilmesinin etkisiyle), reklam yoğunluğunun arttığı sonucuna ulaşmışlardır.

Piyasaya giriş engeli yaratan en önemli olgulardan biri olan reklam faaliyetleri, mal farklılaştırmasında ${ }^{17}$ kullanılan en temel politika araçlarından biridir. Reklam harcamaları bir taraftan firmanın malına uyguladığı limit fiyatı artırırken, diğer taraftan da

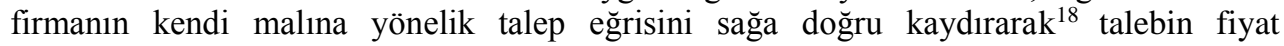
esnekliğini de azaltmaktadır. Comanor ve Wilson (1967) piyasa performansı ve reklam yoğunluğu üzerine yaptıkları çalışmada özellikle mal farklılaştırması yapılabilen endüstrilerde, reklama yapılan yatırımların endüstri kârlılığı üzerinde pozitif ve anlamlı bir etkisi olduğunu sonucuna ulaşmışlardır. Ayrıca Comanor ve Wilson (1967) reklam harcamalarının daha yüksek olduğu endüstrilerde kârlılığın da daha yüksek olduğunu ve bu endüstrilerde reklam harcamaları ile elde edilen piyasa gücünün giriş engelleri yarattığını ileri sürmektedirler. Bununla birlikte, Demsetz (1979) reklam yoğunluğu ile kâr oranları arasında pozitif bir korelasyon olduğunu ve reklam yoğunluğunun yüksek olduğu endüstrilerde kârlılığın da yüksek olduğunu belirtmekle birlikte, reklamın piyasaya giriş engelleri yaratmadığı sonucuna ulaşmıştır.

Bloch (1974), literatürdeki kâr oranları ve reklam yoğunluğu arasında pozitif bir ilişki olduğu sonucuna ulaşılan çalışmalarda genellikle reklam harcamalarının cari harcamalar olarak değerlendirildiğini, bununla birlikte reklam harcamalarının satışlar üzerinde uzun dönemli etkileri olduğunu ve bu yüzden reklam harcamalarını cari harcamalar olarak ele almanın doğru olmadığını ileri sürmektedir. Bu kapsamda Bloch (1974) reklam harcamalarını, sermaye malına yönelik yatırım harcaması gibi ele almış ve bu şekilde hesaplanan düzeltilmiş kârlılık oranları ile reklam yoğunluğu arasındaki ilişkiyi analiz ettiği çalışmasında ise kâr oranları ile reklam yoğunluğu arasında anlamlı bir ilişki olmadığı sonucuna ulaşmıştır. Bununla birlikte Oustapassidis ve Vlachvei (1999) 19881994 yılları arasında Yunanistan'daki gıda sektörü üzerine yaptıkları çalışmada yüksek oranda mal farklılaştırmasının yapıldığ 1 sektörlerde reklamın marka sadakatini artırdığı ve

17 Mal farklılaştırması, satılan malların görünüş, biçim, içerik, renk, tat biçiminde yapılabildiği gibi, satılan malların özellik bakımından birbirinden farklı olmamasına karşın, yalnızca tüketicilerin algılarında söz konusu malın farklı olduğuna yönelik bir imaj yaratma biçiminde de olabilir. Söz konusu imaj ise bazı tüketicilerin malın fiyatı yüksek olmasına karşın, reklamı yoğun malı satın almaya devam etmesine neden olabilmektedir (Comanor and Wilson, 1979).

18 Johnson and Myatt (2006)'a göre reklam ve pazarlama faaliyetlerinin her zaman firmanın satışlarını artıracă̆ (talebini să̆a kaydıracă̆l) varsayımı kısıtlayıcıdır. Çünkü söz konusu faaliyetler tüketicilerin kişisel tercihleriyle malın eşleşip eşleşmediğini öğrenmesini ve mal için kişisel değer biçmesini sağlar ki, bu durum her zaman tüketicilerin talebinde bir artışa neden olmaz. Johnson and Myatt (2006:766) bilginin, yanıltıcı (hypo) ve gerçek bilgi olmak üzere iki türü olduğunu ifade etmektedirler. Mal için yapılan temel tanıtımdaki yanıltıcı bilgi tüketicinin malın varlığını, herhangi bir özelliğini olumlu olarak öne çıkarabilir veya tüketicilerin satın alma istekliliğini artırarak, talebi artırabilir. Bununla birlikte gerçek bilgi tüketicilerin öznel tercihleri çerçevesinde malın özelliklerini eşleştirmesini sağlar. Yani gerçek bilgi tüketicilerin değerlendirmelerinin dağılımını arttırır, diğer bir deyişle talep ĕ̆risinin şeklini (biçimini) değiştirir. 
talebin fiyat esnekliğini azalttığı, dolayısıyla da söz konusu sektörlerde reklamın, kârlılık oranlarındaki farklılığı açıkladığı sonucuna ulaşmışlardır ${ }^{19}$.

Piyasadaki rekabetin yoğun olması durumunda reklam harcamaları malların piyasadaki bilinirliğini artırarak kârlılığı önemli ölçüde etkileyebilmektedir. Ancak, Qian ve Li (2003) ileri teknolojili sektörlerden biri olan biyoteknoloji sektörü üzerine yaptıkları çalışmada piyasa bilinirliği ile kârlılık arasında anlamlı bir ilişki olmadığını sonucu ulaşmışlardır. Qian ve Li (2003) bu durumu küçük ve orta ölçekli firmaların reklam için fazla harcama yapmamalarına bağlarken, bu durum için üç olası açıklama yapmışlardır: Birincisi, ileri teknolojili endüstrilerde düşük düzey maliyet etkinliği eşiği bulunduğu ve bu eşiğin üzerinde reklamın piyasa bilinirliği yaratmada etkili olmayabileceğidir. İkincisi, ileri teknolojili endüstrilerde yeni ürünlerdeki teknolojilerin mükemmel olmayabileceği ve dolayısıyla söz konusu malların satın alımında tüketicilerin reklamdan daha fazla çevrelerindeki kişilerin kişisel deneyimlerini kullandıkları ve bu yüzden de piyasa bilinirliğinin, müşterilerin ikna edilmesine ve satışın gerçekleşmesine neden olmayabileceğidir ${ }^{20}$. Üçüncüsü ise, piyasa bilinirliği yaratmak için kullanılacak büyük reklam harcamaları küçük ve orta ölçekli firmaların rekabet üstünlüklerini ortadan kaldırabilir. Yüksek teknolojili mal üreten endüstriler dışındaki endüstrilerde faaliyette bulunan küçük ve orta ölçekli firmalar ise, ağırlıklı olarak yerel veya bölgesel piyasalarda zaten küçük piyasa paylarıyla çalıştıklarından, RPD faaliyetlerine göreli olarak daha az önem verebilmektedirler. Dolayısıyla geniş bir pazarlama ve dağıtım kanalına sahip büyük firmalar, küçük ve orta ölçekli firmalara oranla, maliyetlerini azaltarak kârlılı̆̆ artırma veya piyasaya giriş engelleri yaratma olanaklarına kavuşmaktadırlar (Porter, 1980). Chiao, Yang ve $\mathrm{Yu}$ (2006)'nun reklama yapılan yatırımların başlangıç aşamasında reklam yoğunluğu ile firma performansı arasında negatif bir ilişkinin olduğu, ancak belirli bir düzeyden sonra reklamın performans üzerindeki etkisinin pozitife döndüğü sav1 ise, özellikle RPD faaliyetlerinden beklenen sonuçların alınması için yapılan harcamaların devamının önemini ortaya koymaktadır. Söz konusu durum ise özellikle küçük ve orta ölçekli firmalar açısından önemli dezavantajları da beraberinde getirebilmektedir.

\subsection{Genel Yönetim Giderleri}

Yönetici özellikleri, firmaların en önemli içsel faktörlerinden biri olarak değerlendirilebilir. Yöneticilerin sahip oldukları nitelikler çerçevesinde almış oldukları kararlar, bir yandan firmanın Ar-Ge, RPD stratejileri ve yatırım kararlarını etkilerken,

19 Oustapassidis ve Vlachvei (1999) mal farklılaştırmasının yüksek olduğu en kârlı sektörlerdeki büyüme oranlarının ve reklam yoğunluğunun da yüksek olduğunu, ancak düşük oranlı mal farklılaştırmasının olduğu sektörlerde reklamın kârlılık oranlarındaki farklılıkları açıklayamadı̆̆ sonucuna ulaşmışlardır. Lee ve Mahmood (2009) da, stratejik yatırım araçları arasında reklam ve Ar-Ge harcamalarının hem endüstri içindeki firmalar arasında hem de endüstriler arasındaki kârlılıktaki farklılıkları açıklamada önemli bir rolü olduğunu ifade etmektedirler.

20 Qian ve Li (2003)'nin bu sonucu Nelson (1974)'un tüketicilerin özellikle fiyatı yüksek olan malları satın almadan önce yalnızca reklama değil, aynı zamanda çevresindeki akraba ve arkadaşlarının yanı sıra tüketici dergilerinin öneri ve görüşlerini alacaklarına yönelik görüşünü destekler niteliktedir. 
diğer yandan firma dışında ulusal veya uluslararası iktisadi koşullarda ortaya çıkan değişimlerin firmaya yansıyabilecek olası olumsuz etkilerinin en aza indirilmesi açısından önemlidir. Leonidou, Katsikeas ve Piercy’e (1998) göre yönetici özellikleri iki bakış açısından incelenebilir. Birincisi yaş, eğitim düzeyi, iş deneyimi, yabancı dil bilgisi gibi yöneticilerin sahip olduğu nesnel faktörlerdir. İkincisi ise riskten kaçınma, kalite, dinamizm, maliyet-kâr ve büyüme algıları gibi öznel faktörlerdir. Söz konusu faktörler literatürde yöneticilerin beşeri ve sosyal sermayelerini içeren yönetim kurulu sermayesi (board capital) olarak da değerlendirilmektedir (Hillman ve Danziel, 2003; Haynes ve Hillman, 2010). Kouser ve ark. (2011), bilgi teknolojisindeki gelişmelerin işlem ve iletişimdeki artışları kolaylaştırarak, firmalardaki maliyetleri azalttığını ifade etmektedir. Özellikle hızla değişen iktisadi ve toplumsal çevreye uyum sağlanabilmesinde, bilgi teknolojisindeki gelişmelerin yakından takip edilmesi gerekmektedir. Bu nedenle söz konusu gelişmeleri değerlendirecek firma yöneticilerinin sahip olduğu nitelikler (Ulusoy, 2003), gerek Ar-Ge faaliyetleri ve RPD, gerekse önemli harcama kalemlerinden biri olan GYG’nin planlanması açısından da önemli bir faktör haline gelmektedir. Dolayısıyla söz konusu süreçlerde yöneticilerin alacakları kararlar, yapacakları harcamalar yöneticilerin niteliklerinden etkilenirken, yöneticilerin aldıkları ücretler ve yaptıkları harcamalar da, hem öznel niteliklerinden hem de söz konusu kararlar sonucunda firmaların elde edeceği kârlardan etkilenecektir. Leahy (2012) Amerika'daki ilaç endüstrisi ve Okwo ve Ugwunta (2012)'nin Nijerya'daki bira firmaları üzerine yaptıkları çalışmalarda satış ve genel yönetim harcamalarının firmaların kârlılığg üzerinde pozitif ve anlamlı bir etkisi olduğu sonucuna ulaşılmıştır.

Golden ve Zajac'a (2001) göre yönetim kurulu büyüklüğünün çok küçük olduğu işletmelerde kuruldakilerin eğitim düzeyi, fonksiyonel geçmişi, mesleği, yaşı, görev süresi, deneyimlerinden elde edilecek yararların firmaların performansı üzerinde anlamlı bir etkisi bulunmaktadır. Ancak bu etki yönetim kurulu büyüklüğü arttıkça azalan getiriye sahiptir. $\mathrm{Bu}$ yüzden, özellikle küçük ve orta büyüklükteki aile işletmelerinde yöneticilerin niteliklerindeki gelişmeler, söz konusu firmaların mal aldıkları firmalarla, müşterileriyle, rakipleriyle, kamu kurumları ve sivil toplum örgütleriyle olan kişisel ve sosyal ilişkilerini geliştirmelerini (Acquaah, 2007) olumlu olarak etkileyerek, gerek firmaların kârlılıklarının gerekse hayatta kalma olasılıklarının artmasına katkı sağlayabilecektir.

Çalışmamızda kullanılan verilerde firma büyüklüklerine göre GYG'nin içeriğiyle ilgili herhangi bir bilgi olmamakla birlikte, Türkiye'de IMKB'de faaliyet gösteren firmaların GYG'sinin içeriği incelendiğinde, GYG içinde yöneticilerin ücretleri, seyahat, danışmanlık, eğitim, haberleşme gibi harcamaların çok büyük bir payı olduğu görülmektedir. Söz konusu harcamaların gerek büyüklüğü, gerekse içeriği genel yönetim kademesinde çalışan yöneticilerin nitelikleri ve aldıkları kararlarla ilişkili olduğu için GYG'deki artışların sektörlerdeki satış kârlılığı üzerinde olumlu etkileri olması beklenmektedir. 


\section{1998-2009 Döneminde Temel Giderlerin ve Brüt Kâr Marjlarının Gelişimi}

Çalışmada 1998-2009 döneminde 9 alt sektördeki küçük, orta ve büyük ölçekli firmaların Ar-Ge, RPD, GYG'nin net satışların kârlılığı üzerindeki etkisi, Türkiye Cumhuriyeti Merkez Bankası imalat sanayii sektör bilançoları verilerinden yararlanılarak analiz edilmektedir. Bu nedenle bu başlık altında söz konusu verilerden yararlanılarak alt sektörlerdeki genel görünüm kısaca özetlenmeye çalışılacaktır ${ }^{21}$.

Türkiye'de genel olarak küçük firmaların net satışları içinde Ar-Ge harcamalarının payları incelendiğinde bütün alt sektörlerde payların çok küçük olduğu görülmektedir. 1998-2009 döneminde küçük firmalarda net satışlar içinde ortalama olarak Ar-Ge'ye en fazla pay elektrikli ve optik aletler $(\% 0,62)$, en düşük pay ise tekstil ve tekstil ürünleri sanayiinde $(\% 0,07)$ ayrılmıştır. Orta ölçekli firmalarda ise Ar-Ge payının, yıllar içinde çok küçük oranlarda dalgalanmakla birlikte, genel olarak çok fazla değişmediği görülmektedir. 1998-2009 döneminde ortalama olarak Ar-Ge paylarında orta ölçekli firmalarda makine ve teçhizat sanayii $(\% 0,47)$, ulaşım araçları sanayii $(\% 0,44)$ ve elektrikli ve optik aletler sanayii $(\% 0,42)$ en yüksek paylara sahip sektörler iken, kâğıt hamuru, kâğıt, kâğıt ürünleri ile yayım ve basım sanayii ve tekstil ve tekstil ürünleri sanayii $(\% 0,07)$ en düşük paya sahip alt sektörlerdir. Son olarak, büyük firmalarda ortalama olarak Ar-Ge harcamalarının net satışlara oranlarında elektrikli ve optik aletler sanayii $(\% 1,14)$, ulaşım araçları sanayii $(\% 1,09)$ ve makine ve teçhizat sanayiinin $(\% 0,88)$ öne çıktığı görülmektedir. Ar-Ge paylarının en düşük olduğu sektörler olarak ise kâğıt $(\% 0,04)$, metal ana sanayii ve işlenmiş metal ürünleri üretimi sanayii $(\% 0,09)$ ve gıda, meşrubat ve tütün ürünleri sanayii - tekstil $(\% 0,14)$ sayllabilir.

Analiz döneminde bütün alt sektörlerde RPD giderlerinin net satışlar içindeki payı \%1 ile \%3 arasında artmıştır. 1998-2009 döneminde küçük firmalarda RPD giderlerinin ortalama olarak en yüksek olduğu sektörler diğer metal dışı madenler sanayii $(\% 6,24)$ ve elektrikli ve optik aletler sanayii $(\% 4,99)$, en düşük olduğu sektörler ise metal ana sanayii ve işlenmiş metal ürünleri üretimi sanayii $(\% 3,29)$ ile tekstil ve tekstil ürünleri sanayi ve ulaşım araçları sanayii $(\% 3,67)$ şeklinde sıralanmaktadır. Orta ölçekli firmalarda ise net satışlar içindeki ortalama en düşük paylar ulaşım araçları sanayii $(\% 3,26)$ ve tekstil $(\% 3,56)$ gerçekleşirken, en yüksek paylar ise diğer metal dışı madenler sanayii $(\% 7,52)$ ve kâğıt hamuru, kâğıt, kâğıt ürünleri ile yayım ve basım sanayiinde $(\% 6,75)$ gerçekleşmiştir. Büyük ölçekli firmalarda RPD harcamalarının net satışlar içindeki payları elektrikli ve optik aletler sanayii (1998 yllında \%5,12'den 2009'da \%3,91'e), kauçuk ve plastik ürünler sanayii (1998 yılında \%8,25'den 2009'da \%6,52'ye), ulaşım araçları sanayiinde (1998 yılında \%5,80'den 2009'da \%4,46’ya) azaldığı görülürken, diğer sektörlerde genel olarak (yaklaşık \%0,5 ile \%3 arasında) artma eğiliminde olduğu görülmektedir. Söz konusu dönemde en yüksek paylarda ise kâğıt hamuru, kâğıt, kâğıt ürünleri ile yayım ve basım

21 1983-2001 döneminde imalat sanayiinde üretkenlik ve teknolojik gelişme için ayrıntılı bilgi için bkz. Taymaz, Voyvoda ve Yllmaz (2008). 
sanayii (ortalaması \%11,32) ve makine ve teçhizat sanayii (ortalaması \%9,04) öne çıkmaktadır.

1998-2009 yılları arasında küçük firmaların GYG'sinin net satışlar içindeki paylarının ya çok fazla değişmemiş, ya da artmıştır. Bununla birlikte orta ve büyük ölçekte firmalarda ise söz konusu payların \%0,5 ile \%2 arasında azalması dikkat çekicidir. Bu durum özellikle küçük işletmelerde aile sahipliğinin göreli olarak daha fazla olduğunun önemli bir göstergesi olarak yorumlanabilir. Söz konusu alt sektörler arasında küçük ölçekli firmalardan ulaşım araçları sanayii GYG'nin payının en fazla arttığı (1998 yılında \%9,95'den 2009'da \%13,82'ye) sektör olmuştur. Gida (+\%0,80) ve tekstil (+\%1 ) GYG'nin payının arttığı diğer sektörlerdir. Orta ölçekli firmaların net satışlar içindeki GYG payları, elektrikli ve optik aletler sektörü dişındaki (1998'de \%5,12'den 2009'da \%5,31'e), diğger alt sektörlerde azalmıştır. Alt sektörler arasında GYG payının 1998-2009 döneminde ortalama olarak en yüksek olduğu sektörler arasında ulaşım araçları sanayii $(\% 7,56)$, kâğıt hamuru, kâğıt, kâğıt ürünleri ile yayım ve basım sanayii $(\% 7,14)$ ve makine ve teçhizat sanayii $(\% 7)$, en düşük olduğu sektörler arasında ise gıda $(\% 3,57)$, tekstil $(\% 4,64)$ ve metal ana sanayii $(\% 4,66)$ bulunmaktadır. Büyük ölçekli firmalarda ise bütün alt sektörlerde GYG'nin net satışlar içindeki payının düştüğü görülmektedir. Payın en fazla düştüğü sektörler arasında elektrikli ve optik aletler sanayii (1998'de \%5,79'dan 2009'da $\% 3,65$ 'e), metal ana sanayii (1998'de \%3,62'den 2009'da \%2'ye) kauçuk ve plastik ürünler sanayiinin (1998'de \%5,06'dan 2009'da \%3,46’ya) öne çıktığg görülmektedir.

1998-2009 döneminde imalat sanayindeki bütün alt sektörlerde net satışların kârlılığında genel olarak önemli düşüşler yaşandığı görülmektedir. Söz konusu dönemde alt sektörler genelinde büyük ölçekli firmalar, satış kârlılıklarının ortalama olarak $(\% 6,34)$ en fazla azaldığı ölçek olmuştur. Orta ölçekli firmalarda net satışların kârlılığı ortalama olarak \%3,7 azalırken, küçük ölçekli firmalarda yalnızca \%0,92 oranında azalmıştır. Küçük ölçekli firmalar arasında kârlılığın ortalama olarak en fazla düştüğü sektörler arasında elektrikli ve optik aletler sanayii $(\% 4,77)$, ulaşım araçları sanayii $(\% 4,65)$ ve metal ana sanayii $(\% 1,81)$ bulunurken, kârlılığın en fazla artığı sektörler arasında gıda $(\% 1,41)$, tekstil $(\% 1,25)$ ve kâğıt hamuru, kâğıt, kâğıt ürünleri ile yayım ve basım sanayii $(\% 1,21)$ yer almaktadır. Orta ölçekli firmalar arasında ise yalnızca kâğıt hamuru, kağıt, kâğıt ürünleri ile yayım ve basım sanayiinde kârlılık ortalama olarak $(\% 2,92)$ artarken diğer bütün alt sektörlerde azalmıştır. Kârlılığın ortalama olarak en çok azaldığı sektörler arasında makine ve teçhizat sanayii $(11,92)$, ulaşım araçları sanayii $(\% 7,47)$, diğer metal dışı madenler sanayii $(\% 5,63)$, metal ana sanayii $(\% 4,42)$, gıda sanayii $(\% 2,97)$ öne çıkmaktadır.

\section{Ekonometrik Yöntem}

Çalışmada ekonometrik yöntem olarak panel veri analizi kullanılmıştır. Panel verileri belli bir zaman boyutuna bağlı olarak kesit verilerinin bir araya getirilmesi ile oluşturulmaktadır. Panel veri yönteminin diğer yöntemlere göre avantajları bulunmaktadır. Bu avantajlardan bazıları şu şekilde sıralanabilir (Baltagi, 2005): 
- Panel veri, belirli bir zaman boyunca kesitler ile ilgili olduğundan bu birimler arasındaki heterojenliği kesite özgü bazı değişkenlere izin vererek dikkate alır.

- Panel veri, kesit ve zaman serisi gözlemlerini birleştirerek daha fazla gözlem sayısı elde edilmesine imkân sağlar.

- Panel veri, değişkenler arasında çoklu doğrusallık problemini (multicollinearity) azaltır ayrıca daha fazla serbestlik derecesi ve daha etkin bir model sağlamaktadır.

Panel veri modelleri aşağıdaki şekilde ifade edilmektedir:

$\mathrm{y}_{\mathrm{it}}=\beta_{1 \mathrm{it}}+\beta_{2 \mathrm{it}} \mathrm{X}_{2 \mathrm{it}}+\ldots+\beta_{\mathrm{kit}} \mathrm{X}_{\mathrm{kit}}+\varepsilon_{\mathrm{it}} \quad \mathrm{i}=1, \ldots, \mathrm{N} \quad \mathrm{t}=1, \ldots, \mathrm{T}$

Denklemde " $\mathrm{i}$ " alt simgesi birimleri, " $\mathrm{t}$ " alt simgesi ise zamanı ifade etmektedir. Panel veri modellerinde her bir kesitin farklı bir sabit terimi olabileceği gibi her bir zaman serisinin de farklı bir sabit terimi olabilmektedir. (1) nolu denkleme $\mu_{\mathrm{it}}$ gözlemlenemeyen spesifik bireysel etkiler eklendiğinde panel veri uygulaması tek yönlü hata bileşeni modeline dönüşürken, bunun yanı sıra gözlemlenemeyen zaman etkileri de modele dahil edilirse bu durumda model iki yönlü hata bileșeni modeline dönüşmektedir. Panel veri analizi başlı̆̆ında üç temel model ele alınabilir. Bunlardan ilki "Havuzlanmış (pool) Regresyon Modeli"dir. Pool regresyon modeli kesin dişsallık, sabit varyans ve ardışık bağımlılı̆̆ın olmadığ Genelleştirilmiş en küçük kareler yöntemi yerine pool regresyon modelini tercih edilebilmesi için modelin gruplara göre değişen varyans testinin yapılması gerekmektedir. Bunun için Lagrange Çarpanı (LM) testi kullanılabilir.

Varyansların birbirine eşit olduğu sıfır hipotezinin reddedilmesi durumunda LM testine göre bu etkilerden en azından biri bulunabilir. Diğer taraftan, bireysel varyansların eşit olduğu varsayılan sıfır hipotezinin reddedilmesi, LM1 testinde bireysel etkileri ortaya çıkarırken, dönemsel varyansların eşit olduğu varsayılan sıfır hipotezinin reddedildiği durumunda LM2 testinde zaman etkisi ortaya çıkacaktır. Bu LM testleri sonuçlarına göre, zaman etkisi yoksa tek yönlü hata bileşeni modeli kullanılabilir. Aksi durumda, iki yönlü hata bileşeni modelinin kullanılması gereklidir.

İkinci model "Sabit Etkiler Modelidir". Her bir yatay kesit verisinin bireysel etkilerini dikkate alarak her bir yatay kesit verisi için sabit katsayılarının farklı olmasına, eğim katsayılarının ise aynı olmasına izin vermektedir. Buradaki sabit etkiler terimi, sabit katsayısının her bir kesit için farklı olmasına rağmen, her bir kesitin sabitinin zaman boyunca değişmemesini ifade etmektedir. Tek yönlü sabit etkiler modeli ile çift yönlü hata düzeltme modeli şu denklemler ile gösterilmektedir:

$\mathrm{y}_{\mathrm{it}}=\left(\alpha_{\mathrm{it}}+\mu_{\mathrm{i}}\right)+\beta_{1 \mathrm{it}} \mathrm{X}_{\mathrm{lit}}+\ldots+\beta_{\mathrm{kit}} \mathrm{X}_{\mathrm{kit}}+\varepsilon_{\mathrm{it}}$

$\mathrm{y}_{\mathrm{it}}=\left(\alpha_{\mathrm{it}}+\mu_{\mathrm{i}}+\lambda_{\mathrm{t}}\right)+\beta_{1 \mathrm{it}} \mathrm{X}_{1 \mathrm{it}}+\ldots+\beta_{\mathrm{kit}} \mathrm{X}_{\mathrm{kit}}+\varepsilon_{\mathrm{it}}$ 
(2) nolu denklemde $\mu_{\mathrm{i}}$ bireyler arasında değişen fakat zaman boyunca değişmeyen sabit katsayısını göstermektedir.

Üçüncü model "Rassal Etkiler Modeli"dir. Rassal etkiler modelinde kesitlere veya hem kesitlere hem de zamana bağl1 olarak meydana gelen değişikler modele hata teriminin bir bileşeni olarak dâhil edilir. Tek yönlü ve çift yönlü rassal etkiler modeli aşağıdaki şekilde oluşturulmaktadır.

$\mathrm{y}_{\mathrm{it}}=\alpha_{\mathrm{it}}+\beta_{1 \mathrm{it}} \mathrm{X}_{\mathrm{it}}+\ldots+\beta_{\mathrm{kit}} \mathrm{X}_{\mathrm{kit}}+\left(\mu_{\mathrm{i}}+\mathrm{v}_{\mathrm{it}}\right)$

$\mathrm{y}_{\mathrm{it}}=\alpha_{\mathrm{it}}+\beta_{1 \mathrm{it}} \mathrm{X}_{\mathrm{it}}+\ldots+\beta_{\mathrm{kit}} \mathrm{X}_{\mathrm{kit}}+\left(\mu_{\mathrm{i}}+\mathrm{v}_{\mathrm{it}}+\lambda_{\mathrm{t}}\right)$

Burada birleşik hata terimi iki bileşenden oluşmaktadır. İlki kesitin zaman boyutunda farkl1lık göstermeyen, kesit etkisini gösteren $\mu_{\mathrm{i}}$ ve ikincisi zaman boyutunda değerleri birbiri ile ilişkili olan geri kalan kısmı gösteren $v_{i t}$ 'dir. Bu modelin En Küçük Kareler (EKK) yöntemi ile tahmin edilmesi ile elde edilen tahminciler tutarlı ve sapmasizdır.

Sabit Etkiler Modeli ve Rassal Etkiler Modellerinden hangisinin kullanılacağ 1 kararının verilebilmesi için Hausman testi yapılmaktadır. Rassal etkiler modelinin en temel varsayımlarından biri modelin birleşik hata terimi ile açıklayıcı değişkenler arasında ilişki olmamasıdır. Bu varsayımının geçerliliği Hausman tarafından geliştirilen bir test istatistiği ile sinanabilmektedir (Green, 2003). Hausman Test istatistiği "rassal etkiler tahmincisi doğrudur." sıfır hipotezi altında yapılmaktadır. Sifır hipotezinin kabul edilmesi halinde hem genelleştirilmiş en küçük kareler tahmincisi hem de grup-içi tahmincisi tutarlı ve etkindir. Sıfır hipotezinin reddedilmesi durumunda ise grup-içi tahmincisi tutarlıdır (Erlat, 2006).

$$
\mathrm{H}_{0}: \mathrm{E}\left(\mathrm{u}_{\mathrm{it}} \mid \mathrm{X}_{\mathrm{it}}\right)=0 \quad \mathrm{H}_{1}: \mathrm{E}\left(\mathrm{u}_{\mathrm{it}} \mid \mathrm{X}_{\mathrm{it}}\right) \neq 0
$$

\subsection{Veri Seti ve Model}

Küçük ve orta ölçekli firmalara yönelik literatürde evrensel olarak kabul edilen bir tanım yoktur ${ }^{22}$. Çalışmada firmaların ölçek büyüklüğüne göre sınıflandırılmasında Türkiye Cumhuriyeti Merkez Bankası'nın sektör bilançolarındaki ${ }^{23}$ çalışan sayısına göre yapılan ölçüt kullanılmıştır ${ }^{24}$. 1998-2009 döneminde ${ }^{25}$ imalat sanayindeki 9 alt sektöre ${ }^{26}$ ait

22 Taymaz (2001, s. 50) evrensel bir tanımın olmamasını üç faktöre bağlamaktadır: Birincisi küçük ve orta ölçekli firmaların homojen bir yapıda olmamalarıdır. İkincisi, bütün ülkelerde farklı kurumların farklı amaçlar için farklı tanımlar yapmasıdır. Sonuncusu ise küçük ve orta ölçekli firmalara ait bilgi eksikliğidir.

23 <http://www.tcmb.gov.tr/sektor/yayinlar.htm>

24 Söz konusu sınıflandırmada çalışan sayısı 50 kişinin altında olan firmalar küçük, 50-500 kişi arasında olan işletmeler orta, 500 kişinin üzerinde olan firmalar ise büyük ölçekli firmalar olarak değerlendirilmektedir.

25 Bazı alt sektörlerde veri eksikliği olduğundan sektör sayısını azaltmamak amacıyla veri setine 2010 ve 2011 yılları dâhil edilememiştir. 
yıllık verilerin kullanıldığı analizde veri seti küçük, orta ve büyük ölçek olarak ayrıştırılarak üç ayrı model tahmini gerçekleştirilmiştir.

Çalışmada Ar-Ge, RPD ve genel yönetim giderleri değişkenlerinin satışların kârlılığı üzerindeki etkisi panel veri analizi yöntemiyle tahmin edilmektedir. Veri seti ölçek bazında ayrıştırılarak, bu etkinin sektörel ölçeğin değişmesi durumunda değişip değişmediğinin görülmesi amaçlanmaktadır. Analizde Andras ve Srinivasan (2003) çalışmasından yararlanılarak kurulan modele D'aveni, Ravenscraft ve Anderson (2004), Okwo ve Ugwunta (2012) ve Leahy (2012) tarafindan kullanılan GYG'nin net satışlara oranı değişkeni eklenerek aşağıdaki model tahmin edilmiştir:

KÂRLILIK ${ }_{i}=\beta_{0}+\beta_{1}^{8} \mathrm{ARGE}_{\mathrm{i}}+\beta_{2}^{8} \mathrm{RPD}_{\mathrm{i}}+\beta_{3}^{8} \mathrm{GYG}_{\mathrm{i}}+\varepsilon_{\mathrm{i}}$

Modelde bağımlı değişken KÂRLILIK , i. alt sektörlerde satışların kârlılığını ${ }^{27}$ (return on sales); $A R G E_{i}$ i. alt sektörün net satışları içindeki Ar-Ge yoğunluğunu; $R_{P} D_{i}$ i. alt sektörün net satışları içinde RPD harcamaları yoğunluğunu; $\mathrm{GYG}_{\mathrm{i}}$ ise $\mathrm{i}$. alt sektörde net satışlar içinde GYG’nin payını göstermektedir.

\subsection{Panel Birim Kök Testi}

Modelin tahmin aşamasına geçmeden önce analizde kullanılan değişkenlere yönelik birim kök testlerinin yapılması gerekmektedir. Durağan olmayan seriler ile çalışılması durumunda tahmin sonucu güvenilir olmamakta, sahte regresyon problemi ortaya çıkmaktadır (Granger ve Newbold, 1974). Panel veri analizinde sıkça kullanılan durağanlık testleri Levin, Lin\&Chu t-testi, Im, Pesaran and Shin W-stat testi, ADF - Fisher Chi-square testi ve PP - Fisher Chi-square sonuçları Tablo: 1'de gösterilmektedir. Buna göre; tüm seriler \%1 anlamlılık düzeyinde birim kök içermemekte olup, serilerin düzeyleri durağandır.

26 (1) Diğer metal dişı madenler sanayii, (2) Elektrikli ve optik aletler sanayii, (3) Gıda, meşrubat ve tütün ürünleri sanayii, (4) Kâğıt, kâğıt hamuru, kâğlt ürünleri ile yayım ve basım sanayii, (5) Makine ve teçhizat sanayii, (6) Metal ana sanayii ve işlenmiş metal ürünleri üretimi sanayii, (7) Kâğlt hamuru, kă̆lt, kâğlt ürünleri ile yayım ve basım sanayii, (8) Tekstil ve tekstil ürünleri sanayii, (9) Ulaşım araçlarl sanayii.

27 Modelde satışların kârlılığının bağımlı değişken olarak alınmasının nedeni, özellikle kârlılık üzerindeki vergi ve finansal büyüklüklerin etkilerinin dişlanarak, modeldeki değişkenlerin gerçek etkilerini belirleyebilmektir. Satışların kârlılı̆̆l = (net satışlar - satışların maliyeti) / net satışlar, biçiminde hesaplanmıştır. 
Tablo: 1

\section{Panel Birim Kök Testi Sonuçları}

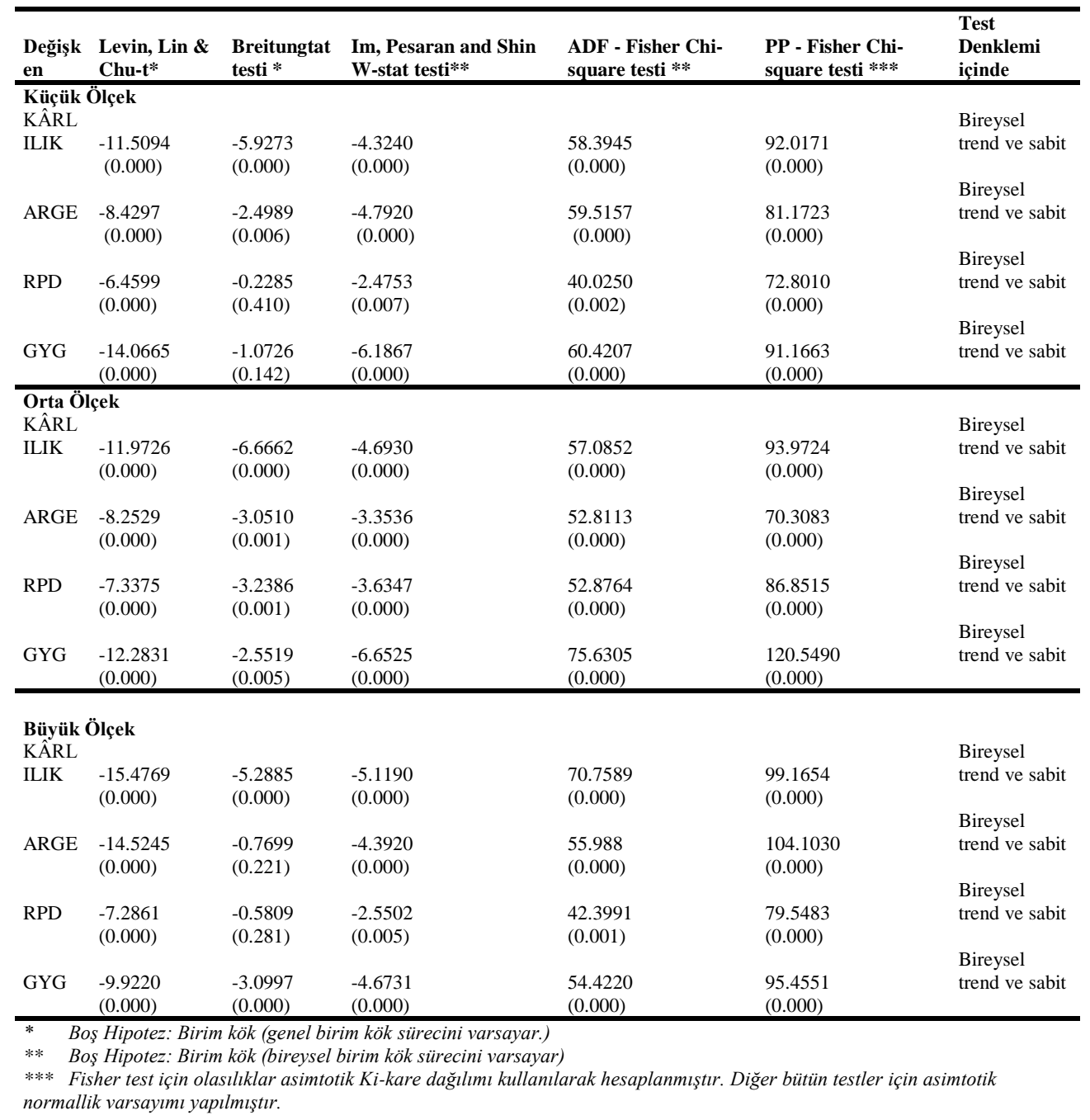

\subsection{Ampirik Sonuçlar} gösterilmektedir.

Model seçiminin ilk aşaması olarak yapılan LM test sonuçları Tablo: 2'de 
Tablo: 2

Panel Regresyon Sonuçları

\begin{tabular}{|c|c|c|c|c|c|c|}
\hline Bağımsız Değişkenler & Küçük Ölçek & & Orta Ölçek & & Büyük Ölçek & \\
\hline ARGE & $\begin{array}{l}0.8275 \\
(0.485)\end{array}$ & & $\begin{array}{l}8.4839 * \\
(2.924)\end{array}$ & & $\begin{array}{l}1.8940 * * \\
(1.997)\end{array}$ & \\
\hline RPD & $\begin{array}{l}0.4161 * * * \\
(1.697)\end{array}$ & & $\begin{array}{l}0.9871 * \\
(4.689)\end{array}$ & & $\begin{array}{l}0.8657 * \\
(7.145)\end{array}$ & \\
\hline GYG & $\begin{array}{l}0.2388 \\
(0.743)\end{array}$ & & $\begin{array}{l}0.5758 \\
(1.188)\end{array}$ & & $\begin{array}{l}2.2973 * \\
(7.250)\end{array}$ & \\
\hline Sabit & $\begin{array}{l}0.1422 * \\
(4.734)\end{array}$ & & $\begin{array}{l}0.0701 * \\
(3.201)\end{array}$ & & $\begin{array}{l}0.0393 * \\
(4.475)\end{array}$ & \\
\hline R2 (Adj.) & 0.810 & & 0.680 & & 0.781 & \\
\hline F-stat & 44.822 & & 16.723 & & 123.638 & \\
\hline Prob (F-stat) & 0.000 & & 0.000 & & 0.000 & \\
\hline $\begin{array}{l}\text { Durbin-Watson } \\
\text { stat }\end{array}$ & 1.272 & 1.799 & & 1.333 & & \\
\hline LM testi & $\begin{array}{l}27.960150 \\
0.000000^{*}\end{array}$ & $\begin{array}{l}\text { Bireysel ya da } \\
\text { zaman etkisi }\end{array}$ & $\begin{array}{l}39.661460 \\
0.000000 *\end{array}$ & $\begin{array}{l}\text { Bireysel ya da } \\
\text { zaman etkisi }\end{array}$ & $\begin{array}{l}9.075074 \\
0.002591\end{array}$ & $\begin{array}{l}\text { Bireysel ya da } \\
\text { zaman etkisi }\end{array}$ \\
\hline LM1 testi & $\begin{array}{l}15.136310 \\
0.000100^{*}\end{array}$ & Bireysel etki var & $\begin{array}{l}4.266903 \\
0.038862\end{array}$ & Bireysel etki yok & $\begin{array}{l}2.987046 \\
0.083933\end{array}$ & Bireysel etki yok \\
\hline LM2 testi & $\begin{array}{l}12.823850 \\
0.000342\end{array}$ & Zaman etkisi var & $\begin{array}{l}35.394560 \\
0.000000 *\end{array}$ & Zaman etkisi var & $\begin{array}{l}6.088028 \\
0.013610\end{array}$ & Zaman etkisi var \\
\hline
\end{tabular}

* Katsaylların \%1, **\%5 ve ***\%10 düzeyinde anlamlı olduğunu ifade etmektedir.

LM testi sonuçlarına göre tüm ölçek gruplarında bireysel ya da zaman etkisi bulunduğu sonucuna ulaşılmaktadır. LM1 testi sonuçlarına göre ise $\mathrm{H}_{0}=\sigma \mu^{2}=0$ hipotezi küçük ölçek grubunda reddedilemediğinden modelde bireysel etki bulunurken, orta ve büyük ölçek modellerinde bu hipotez reddedilmektedir. LM2 testi sonucuna göre ise $\mathrm{H}_{0}=$ $\sigma_{\lambda}{ }^{2}=0$ hipotezi reddedilememektedir. Dolayısıyla her üç modelde de zaman etkisi gözükmektedir. Model tahminine geçilmeden önce Sabit Etkiler ve Rassal Etkiler modelleri arasında tercih yapabilmek için Hausman testi yapılmıştır. Ek 1'de Hausman testi sonuçları sunulmuştur. Küçük ölçek modelinde birim etkilerin Sabit Etkiler, dönem etkilerinin ise Rassal olduğu sonucuna ulaşlırken, orta ölçek modelinde $\% 1$ anlamlılık düzeyinde Sabit Etkiler modelinin, büyük ölçek modelinde ise Rassal Etkiler modelinin etkin olduğu kararına varılmıştır. Ayrıca modellerin hata terimlerinde otokorelasyon ve/veya değişen varyans sorunlarının olup olmadığını belirlemek amacıyla yapılan testlerin ${ }^{28}$ sonucuna göre tüm modellerde otokorelasyon problemi tespit edilirken, orta ölçek modeli dişındaki modellerde değişen varyans probleminin de bulunduğu sonucuna ulaşılmıştır. $\mathrm{Bu}$ problemlerin giderilmesi amacıyla tüm modellerin tahmininde White Dönemsel Standart Hata ve Kovaryans düzeltme yöntemi kullanılmıştır. Küçük ölçek modelinin tahmin sonuçlarına bakıldığında sadece RPD değişkeninin katsayısı \%10 düzeyinde anlamlı bulunurken, orta ölçek modelinde GYG dışındaki tüm değişkenlerin katsayıları anlamlıdır. Orta ölçek modelinde kârlılığı en çok etkileyen ARGE değiş̧kenindeki bir birimlik artışın kârlılığı 8,48 birim artırdığı görülmektedir. Büyük ölçek modelinde ise tüm değişkenlerin kârlılık üzerindeki etkisi anlamlı bulunurken, en büyük etkinin GYG değişkenine ait olduğu sonucuna ulaşılmıştır.

28 Otokorelasyon testi sonuçları Ek 2'de ve Değişen Varyans Testi sonuçları Ek 3'de sunulmuştur. 


\section{Sonuç}

Aynı endüstri içinde veya farklı endüstrilerdeki kârlılık oranlarındaki farklılıklar, kârlılık ile firma büyüklüğü arasındaki ilişkinin analizine yönelik çalışmaları sürekli gündemde tutmaktadır. Söz konusu farklılıklarda firmaların temel harcama kalemlerinden Ar-Ge, RPD ile GYG'nin etkileri de literatürde yoğun olarak çalışılan alanlardan biridir. Çalışmamızda firma büyüklüğü ile kârlılık arasındaki ilişki yerine, küçük, orta ve büyük ölçekte firmalarda bu temel harcama kalemlerinin kârlılık üzerindeki etkisi analiz edilmiştir.

Ar-Ge faaliyetleri bir taraftan firmaların kârlılığını artırırken, diğer taraftan kârlılıktaki artışlarda Ar-Ge faaliyetlerinin sürdürülebilmesinde ve firmaların hayatta kalma ve büyüme olasılıklarının artmasında oldukça önemlidir. Genel olarak Türkiye'de firmaların Ar-Ge harcamalarının net satışlar içindeki paylarının çok düşük olduğu ve söz konusu payların, hemen hemen sektörlerin tamamında, azaldığı görülmektedir. Küçük ölçekteki firmalar sınırlı finansman olanaklarıyla Ar-Ge'ye en az pay ayırabilen firmalardır ki, analizde küçük ölçekteki firmalarda Ar-Ge harcamalarının kârlılık üzerinde anlamlı bir etkisinin olmadığı görülmektedir. Orta ölçekli firmalarda Ar-Ge harcamalarının kârlılık üzerindeki etkisi $(8,48)$ büyük firmalara $(1,89)$ oranla daha büyüktür. Link ve Rees $(1990)$ ile Audretsch ve Vivarelli (1996) küçük ve orta ölçekli firmaların üniversite ile işbirliğinden elde ettikleri bilgileri (veya kamu desteğini -Özçelik ve Taymaz, 2008) daha etkin kullanarak, firma içindeki yaptıkları Ar-Ge faaliyetlerinin getirilerini büyük firmalara oranla daha fazla artırdıkları sonucuna ulaşmıştırlar. Analiz sonuçlarına göre, özellikle küçük ve orta ölçekli firmaların Ar-Ge faaliyetlerine yönelik olarak, gerek üniversitesanayi işbirliğini geliştirecek politikaların, gerekse vergi, teşvik, sübvansiyon gibi mali katkıların önemi açıkça ortaya çıkmaktadır. Söz konusu politikalarla elde edilecek başarılar, bir taraftan ülkenin fiziki üretim kapasitesinin, diğer taraftan firmaların uluslararası düzeyde rekabet gücünün artırılmasında önemli katkılar sağlayabilir.

Reklam, pazarlama ve satış harcamalarının bütün ölçeklerde kârlılık üzerinde pozitif ve anlamlı bir etkisi olduğu görülmektedir. Küçük firmalarda, genellikle yerel ve/veya bölgesel düzeyde faaliyette bulunmalarının da etkisiyle, reklam, pazarlama ve satış harcamalarının kârlılık üzerinde etkisinin $(0,41$ birim) göreli olarak küçük çıktığı görülmektedir. Veri seti incelendiğinde, büyük firmaların net satışları içindeki reklam, pazarlama ve satış harcamaları payının, orta ölçekli firmalara oranla daha yüksek olmasına karşın, reklam, pazarlama ve satış harcamalarındaki bir birimlik artışın orta ölçekli firmalardaki kârlılık üzerindeki etkisinin ( 0,98 birim), büyük ölçekli firmalardan $(0,86$ birim) daha fazla olduğu görülmektedir.

Firmaların ölçekleri büyüdükçe eğitim, bilgi, deneyim, yabancı dil gibi açılardan daha nitelikli kişilerin yönetim kademesindeki sayısı artmaktadır. Yüksek nitelikli ve profesyonel yöneticiler ise gerek firmaların yatırım, Ar-Ge, reklam, pazarlama ve dağıtım gibi alanlardaki alacakları kararlarda, gerek firma dışındaki tüketici, diğer firmalar, sivil toplum örgütleri ve kamuyla kurdukları ilişkilerde, gerekse ulusal ve/veya uluslararası düzeyde iktisadi koşullardaki değişimlerin firmaya yönelik olası olumsuz etkilerin en aza indirilmesinde önemli roller üstlenmektedir. Analiz sonuçları bu rollerin 
önemini açıkça ortaya koymaktadır. Küçük ve orta ölçekli firmalarda GYG’nin kârlılık üzerinde anlamlı bir etkisi söz konusu değilken, büyük ölçekli firmalarda GYG’nin $(2,29)$ kârlılık üzerindeki etkisinin Ar-Ge $(0,86)$, ve RPD $(1,89)$ harcamalarından daha fazla bir etkiye sahip olması dikkat çekicidir. Bu sonuçlar, imalat sanayiinde özellikle büyük ölçekli firmalarda, yönetici niteliklerinin ve nitelikler çerçevesinde alınan kararların kârlılık üzerinde çok önemli etkileri olduğunu göstermektedir.

Çalışmadaki sonuçlar, Türkiye'de, özellikle küçük ve orta ölçekli firmaların işgücüne, sahiplerine ve/veya yöneticilerine yönelik üretim, Ar-Ge, pazarlama, dağıtım ve yönetim gibi birçok konuda yapılabilecek eğitim faaliyetleri ve/veya mali destekler ile üniversite-sanayi işbirliğinin geliştirilmesinin, gerek firmaların gelişiminde gerekse ülkenin kalkınmasında ne kadar önemli olduğunu açıkça ortaya koymaktadır.

\section{Kaynakça}

Acs, Z.J. \& D.B. Audretsch (1988), "Innovation in Large and Small Firms: An Empirical Analysis", The American Economic Review, 78(4), 678-690.

Acs, Z.J. \& D.B. Audretsch (1989), "Small-Firm Entry in US Manufacturing”, Economica, New Series, 56(222), 255-265.

Acquaah, M. (2007), “Managerial Social Capital Strategic Orientation, and Organizational Performance in An Emerging Economy", Strategic Management Journal, 28(12), 1235 1255 .

Ahn, S. (2001), "Firm Dynamics and Productivity Growth: A Review of Micro Evidence from OECD Countries", OECD Economics Department Working Papers, No. 297, OECD Publishing.

Akbaş, H.E. \& H.A. Karaduman (2012), "The Effect of Firm Size on Profitability: An Empirical Investigation on Turkish Manufacturing Companies", European Journal of Economics Finance and Administrative Sciences, 55, 21-27.

Alchian, A.A. (1965), "The Basis of Some Recent Advances in The Theory of Management of The Firm", The Journal of Industrial Economics, 14(1), 30-41.

Amato, L. \& R.P. Wilder (1985), "The Effects of Firm Size on Profit Rates in U. S. Manufacturing”, Southern Economic Journal, 52(1), 181-190.

Ammar, A. vd. (2003), "Indicator Variables Model of Firm's Size-Profitability Relationship of Electrical Contractors Using Financial and Economic Data", Journal of Construction Engineering and Management, 129(2), 192-197.

Andras, T.L. \& S.S. Srinivasan (2003), “Advertising Intensity and R\&D Intensity: Differences Across Industries and Their Impact on Firm's Performance", International Journal of Business and Economics, 2(2), 81-90.

Archarungroj, P. \& Y. Hoshino (1999), "Firm Size and R\&D on Profitability: An Empirical Analysis on Japanese Chemical and Pharmaceutical Industry", Japanese Journal of Administrative Science, 13(2), 71 - 86. 
Audretsch, D.B. (1991), "New-Firm Survival and The Technological Regime”, The Review of Economics and Statistics, 73(3), 441-450.

Audretsch, D.B. \& M. Vivarelli (1996), "Firm Size and R\&D Spillovers: Evidence from Italy", Small Business Economics, 8, 249-258.

Audretsch, D.B. \& P. Houweling \& A.R. Thurik (2000), "Firm Survival in The Netherlands", Review of Industrial Organization, 16, 1-11.

Baltagi, B.H. (2005), Econometric Analysis of Panel Data, John Wiley and Sons, New York.

Bagwell, K. (2007), "The Economic Analysis of Advertising”, Handbook of Industrial Organization, 3, 1701-1844.

Bass, F.M. \& P. Cattin \& D.R. Wittink (1978), "Firm Effects and Industry Effects in The Analysis of Market Structure and Profitability", Journal of Marketing Research, 15(1), 3-10.

Becchetti, L. \& G. Trovato (2002), "The Determinants of Growth for Small and Medium Sized Firms, The Role of The Availability of External Finance", Small Business Economics, 19, 291-306.

Beck, T. \& A. Demirguc-Kunt (2006), "Small and Medium-Size Enterprises: Access to Finance as A Growth Constraint", Journal of Banking \& Finance, 30, 2931-2943.

Beck, T. \& A. Demirguc-Kunt \& V. Maksimovic (2005), "Financial and Legal Constraints to Growth: Does Firm Size Matter?”, The Journal of Finance, 60(1), 137-177.

Bloch, H. (1974), “Advertising and Profitability: A Reappraisal”, Journal of Political Economy, 82(2), 267-286.

Candemir A. \& A.A. Zalluhoğlu (2011), "The Effect of Marketing Expenditures During Financial Crisis: The Case of Turkey”, Procedia Social and Behavioral Sciences, 24, 291-299.

Carpenter, R.E. \& B.C. Petersen (2002), "Is The Growth of Small Firms Constrained by Internal Finance?", The Review of Economics and Statistics, 84(2), 298-309.

Caves, R.E. \& M.E. Porter (1977), "From Entry Barriers to Mobility Barriers: Conjectural Decisions and Contrived Deterrence to New Competition", The Quarterly Journal of Economics, 91(2), 241-262.

Chandler, A.D. (1992), "Organizational Capabilities and The Economic History of The Industrial Enterprise", The Journal of Economic Perspectives, 6(3), 79-100.

Chiao, Yu-Ching, Yang, Kuo-Pin, \& Yu, Chwo-Ming, P. (2006), "Performance, Internationalization, and Firm-Specific Advantages of SMEs in A Newly-Industrialized Economy", Small Business Economics, 26,475-492.

Comanor, W.S. (1967), "Market Structure, Product Differentiation and Industrial Research", The Quarterly Journal of Economics, 81(4), 639-657.

Comanor, W.S. \& T.A. Wilson (1967), "Advertising Market Structure and Performance”, The Review of Economics and Statistics, 49(4), 423-440.

Comanor, W.S. \& T.A. Wilson (1979), "The Effect of Advertising on Competition: A Survey", Journal of Economic Literature, 17(2), 453-476. 
Demsetz, H. (1979), “Accounting for Advertising As A Barrier to Entry”, The Journal of Business, 52(3), 345-360.

Dhawan, R. (2001), "Firm Size and Productivity Differential Theory and Evidence From A Panel of US Firms", Journal of Economic Behavior \& Organization, 44, 269-293.

D’Aveni, R.A. \& D.J. Ravenscraft \& P. Anderson (2004), "From Corporate Strategy to BusinessLevel Ddvantage: Relatedness as Resource Congruence", Managerial and Decision Economics, 25, 365-381.

Erlat, H. (2006), “Panel Data: A Selective Survey”, Discussion Paper Series, No. 97-04, Department of Economics Middle East Technical University.

García-Manjón, J.V. \& M.E. Romero-Merino (2012), "Research, Development, and Firm Growth. Empirical Evidence from European Top R\&D Spending Firms”, Research Policy, 41, 1084- 1092.

Golden B.R. \& E.J. Zajac (2001), "When Will Boards Influence Strategy? Inclination x Power = Strategic Change”, Strategic Management Journal, 22(12), 1087-1111.

Granger, C.W.J. \& P. Newbold (1974), “Spurious Regressions in Econometrics”, Journal of Econometrics, Elsevier, 2(2), 111-120.

Green, W.H. (2003), Econometric Analysis, Prentice Hall, New Jersey.

Hall, B.H. \& J. Lerner (2009), "The Financing of R\&D and Innovation", National Bureau of Economic Research, Working Paper No.15325, September, Cambridge.

Hansen, G.S. \& B. Wernerfelt (1989), "Determinants of Firm Performance The Relative Importance of Economic and Organizational Factors", Strategic Management Journal, 10(5), 399411.

Haynes, K.T. \& A. Hillman (2010), "The Effect of Board Capital and CEO Power on Strategic Change", Strategic Management Journal, 31, 1145-1163.

Hillman A.J. \& T. Danziel (2003), "Boards of Directors and Firm Performance: Integrating Agency and Resource Dependence Perspectives", Academy of Management Review, 28(3), 383396.

Johnson, J.P. \& D.P. Myatt (2006), "On The Simple Economics of Advertising, Marketing, and Product Design”, The American Economic Review, 96(3), 756-784.

Kouser, R. vd. (2011), "Firm Size, Leverage and Profitability: Overriding Impact of Accounting Information System", Business and Management Review, 1(10), 58-64.

Laporta, P. \& A.W. Jenkins (1996), "Unionization and Profitability in The Canadian Manufacturing Sector”, Relations Industrielles / Industrial Relations, 51(4), 756-777.

Leahy, A.S. (2012), "The Determinants of Profitability in The Pharmaceutical Industry", American Journal of Health Sciences, 3(1), 37-41.

Lee, Chang-Yand, \& I.P. Mahmood (2009), "Inter-industry Differences in Profitability The Legacy of The Structure-Effiency Debate Revisited", Industrial and Corporate Change, 18(3), 351-380. 
Leonidou, L.C. \& C.S. Katsikeas \& N.F. Piercy (1998), "Identifying Managerial Influences on Exporting: Past Research and Future Directions". Journal of International Marketing, 6(2), 74-102.

Licht, G. \& E. Nerlinger (1998), “New Technology-Based Firms in Germany: A Survey of The Recent Evidence", Research Policy, 26, 1005-1022.

Link, A.N. \& J. Rees (1990), "Firm Size, University Based Research and The Returns to R\&D”, Small Business Economics, 2, 25-31.

Okwo, I.M. \& D.O. Ugwunta (2012), “Impact of Firm's Input Costs on Firm Profitability: Evaluation of The Nigerian Brewery Industry", Research Journal of Finance and Accounting, 3(6), 78-89.

McAlister, L., Srinivasan, R. \& Kim, M. (2007), Advertising, Research and Development, and Systematic Risk of The Firm, Journal of Marketing, 71, 35-48.

McGee, J. \& H. Thomas (1986), “Strategic Groups Theory Research and Taxonomy”, Strategic Management Journal, 7(2), 141-160.

Nadiri, M.I. \& S. Kim (1996), "R\&D, Production Structure and Productivity Growth: A Comparison of The US, Japanese, and Korean Manufacturing Sectors", NBER Working Paper, No. 5506, Massachusetts, Cambridge.

Nelson, P. (1974), “Advertising as Information”, Journal of Political Economy, 82(4), 729-754.

Nelson, R.R. (1991), "Why Do Firms Differ, and How Does It Matter?", Strategic Management Journal, 12, 61-74.

Oustapassidis, K. \& A. Vlachvei (1999), "Profitability and Product Differentiation in Greek Food, Industries", Applied Economics, 31, 1293-1298.

Özçelik, E. \& E. Taymaz (2004), "Does Innovativeness Matter For International Competitiveness in Developing Countries? The Case of Turkish Manufacturing Industries", Research Policy, 33, 409-424.

Özçelik, E. \& E. Taymaz (2008), "R\&D Support Programs In Developing Countries: The Turkish Experience", Research Policy, 37, 258-275.

Phillips, B.D. (1991), "The Increasing Role of Small Firms in The High-Technology Sector: Evidence From The 1980s", Business Economics, 26, 40-47.

Porter, M.E. (1980), "Industry Structure and Competitive Strategy: Keys to Profitability", Financial Analysts Journal, 36(4), 30-41.

Qian, G. \& L. Li (2003), "Profitability of Small and Medium Sized Enterprises in High Tech Industries The Case of The Biotechnology Industry", Strategic Management Journal, 24, 881-887.

Scherer, F.M. (2001), "The Link Between Gross Profitability and Pharmaceutical R\&D Spending", Health Affairs, 20(5), 216-220.

Taymaz, E. (2001), "Small and Medium Sized Enterprises in Turkish Manufacturing Industries", Journal of Economic Cooperation, 22(1), 43-72. 


\section{Cemil ÇífTÇi}

Taymaz, E. \& E. Voyvoda \& K. Yılmaz (2008), “Türkiye İmalat Sanayiinde Yapısal Dönüşüm Üretkenlik ve Teknolojik Değişme Dinamikleri”, ERC Working Papers in Economics 08/04, METU, November.

Ulusoy, G. (2003), "An Assessment of Supply Chain and Innovation Management Practices in The Manufacturing Industries in Turkey", International Journal of Production Economics, 86, 251-270.

Vernon, J.M. \& R.E.M. Nourse (1973), "Profit Rates and Market Structure of Advertising Intensive Firms", The Journal of Industrial Economics, 22(1), 1-20.

Williamson, O.E. (1963), "Managerial Discretion and Business Behavior", The American Economic Review, 53(5),1032-1057.

\section{Ek: 1}

\section{Hausman Testi Sonuçları}

\begin{tabular}{lccc}
\hline Test Değerleri & Ki-kare & & \\
\hline Küçük Ölçek & Ki-kare(3)) & d.f. & Prob. Değeri \\
LM testi (birim) & 14.996145 & 3 & 0.0018 \\
LM testi (period) & 6.496446 & 3 & $0.0898^{*}$ \\
\hline Orta Ölçek & 10.103063 & 3 & 0.0177 \\
LM testi (period) & & & $0.1514^{*}$ \\
\hline Büyük Ölçek & 5.295587 & 3 & \\
LM testi (period) &
\end{tabular}

Ek: 2

Otokorelasyon Testi Sonuçları

\begin{tabular}{llcc}
\hline Test Değerleri & & Lmrho_Ki-Kare(2) & Prob. Değeri \\
\hline Küçük Ölçek & Sabit Etki & 8.565902 & 0.003425 \\
& Rassal Etki & 17.854850 & 0.000133 \\
\hline Orta Ölçek & Sabit Etki & 8.888337 & 0.002870 \\
\hline Büyük Ölçek & Rassal Etki & 22.838410 & 0.000011 \\
\hline
\end{tabular}

Ek: 3

Değişen Varyans Testi Sonuçları

\begin{tabular}{lcc}
\hline Test Değerleri & Lmrho_Ki-Kare(8) & Prob. Değeri \\
\hline Küçük Ölçek & 19.258690 & 0.013536 \\
Orta Ölçek & 0.013536 & 0.088461 \\
Büyük Ölçek & 21.203390 & 0.006626 \\
\hline
\end{tabular}

